\title{
34 VIRTUAL ORGANISATIONS AND THE WEB SITE RESOURCE
}

\author{
Craig Standing*, Girija Krishnaswamy \\ Edith Cowan University, Australia
}

\begin{abstract}
Virtual organisations often rely heavily on their Web sites. Indeed, Web sites have taken on strategic importance within such organisations as the dependence on face-to-face communication and physical location decreases. Despite this, many organisations are still experimenting with alternative methods of managing their Web site resource. This paper explores alternative methods of managing Web sites and presents some of the key strengths and weaknesses with each approach. Examples of how more traditional organisations manage their sites are examined to provide suggestions and guidelines for virtual organisations in this topic of strategic importance.
\end{abstract}

\section{INTRODUCTION}

There are a number of characteristics that are commonly used to define the term virtual corporation. A key feature of virtual corporations is that they form structures which are made up of different companies or individuals that come together to complete certain tasks and therefore appear as one organisation to the customer or client. The communication, cooperation and coordination related to their work are enabled through the use of information technology.

This paper explores the issues surrounding the on-going management of Web sites as an organisational, customer/client and supplier resource. In particular, the aim is to determine the strategies organisations use to manage their Web resource and analyse their main strengths and weaknesses.

Six studies of organisations that have large Web sites are used to illustrate the nature of the problems and anomalies that can sometimes arise in large organisations in relation to Web site management. Although these are not virtual organisations, the experiences and findings will be of benefit to virtual organisations in the management of their Web resources. Finally, appropriate management structures and strategies for Web site management for virtual organisations are discussed.

\footnotetext{
- School of Management Information Systems, Edith Cowan University, Joondalup, Western Australia, tel.: + 61894005545 , fax: + 61894005633 , e-mail: c.standing@cowan.edu.au
}

The original version of this chapter was revised: The copyright line was incorrect. This has been corrected. The Erratum to this chapter is available at DOI: 10.1007/978-0-387-35577-1_37 


\section{VIRTUAL ORGANISATIONS AND WEB TECHNOLOGY}

The Internet or intranet applications of a virtual enterprise requires careful thought and consideration just as with non-virtual organisations. Indeed, due to the heavy emphasis on the use of communications technology in virtual organisations and the geographically distributed nature of these organisations it could be assumed that the Web site would be even more strategically significant.

Virtual organisations or teams must share data, information and knowledge. This type of organisational structure is typically formed to explicitly share knowledge. Knowledge management can be improved by accessing the organisational memory with the aid of information technology. The richer the knowledge representations the more knowledge that should be communicated (Yap \& Niels-Anderson, 1998). Organisational Web sites, whether internet or intranet, can play a strategic role in providing a rich medium for knowledge communication.

Despite the plethora of articles being written about virtual organisations there is still some ambiguity over certain features of them. It could be argued, for example, that there are degrees of virtuality. Some organisations may interact totally by information and communications technology whilst others may intersperse face-toface communication. It is assumed in the literature that virtual organisations need to be flexible to cope with a variety of tasks and locations. However, there are varying degrees of flexibility and it is a relative concept. Trust is often viewed as an important characteristic of virtual organisations (Rittenbruch, Kahler, Cremens, 1998) but some studies conclude that it is no more significant in virtual organisations than it is in non-virtual organisations (Staples \& Ratnasingham, 1998).

A commonly proposed characteristic of virtual enterprises is that they operate with some informality and with a flatter management structure than the traditional hierarchies found in many bureaucratic organisations (Rittenbruch, Kahler, Cremens, 1998). Ahuja \& Carley, (1998) suggest that this is an over-simplification of the management approaches required in virtual environments. They argue that the management approach (centralised/hierarchical or flatter/decentralised) should depend on the task or the project being undertaken.

There is general confusion over management approaches and structures in virtual organisations. This paper examines approaches used for managing Web resources (Internet and intranet) in non-virtual organisations but discusses the issues and implications of the findings for virtual organisations.

\section{MANAGEMENT STRATEGIES FOR WEB SITE EVOLUTION}

The particular focus of this paper is to discuss appropriate strategies for Web site management and the strengths and problems associated with them. Any organization planning to have a Web site must evolve a strategy for effective use of the Web site. Organizational goals should be clearly spelt out so as to integrate the Web site into organizational information systems, organizational image and objectives. The major management issues in relation to Web resources can be summarised as:

Strategy
Staffing
Functionality
Design
Publishing-ownership

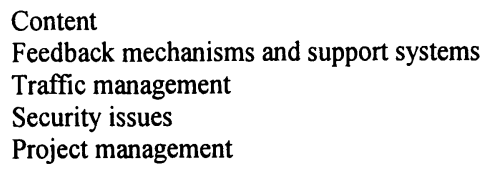




\section{Management Structures}

Management structures and approaches are a well documented topic of study in the management discipline (Vecchio, Hearn, Southey, 1996; Robbins, Millet, Cacioppe, Waters-Marsh, 1998; Bartol, Martin, Tein, Matthews, 1998). A range of organisational forms and associated management structures have been documented that lie between the extremes of bureaucratic and organic. They include the following structures (Robbins, Millet, Cacioppe, Waters-Marsh, 1998).

Bureaucratic - characterised by rules and procedures, hierarchical chain of command, division of labour and specialisation, emphasis on record keeping, centralised decision making.

Simple - low degree of departmentalisation, wide spans of control, authority centralised in a single person, and little formalisation.

Matrix - dual lines of authority, combines functional and product departmentalisation.

Team - the use of teams as a central device to coordinate work activities, decentralised decision making to the team level, cross-functional, works within a bureaucratic framework.

Organic - low horizontal differentiation, adaptable duties, low formalisation, informal communication, decentralised decision authority.

These organisational structures are managed by equivalent management structures and styles. Even though these styles are usually viewed as organisational in their scope, this need not necessarily be so. A department or branch could be run along different lines to the rest of the organisation and one resource could be managed in a different way to other resources.

\section{Bureaucratic Web Site Management}

It has been recognised that there are advantages and disadvantages associated with bureaucracies (Vecchio, Hearn, Southey, 1996). Table 1 examines the pluses and minuses of a bureaucratic approach for Web site management. For virtual organisations this analysis raises relevant issues for how they manage their own Web resources. Even though it is commonly assumed that virtual organisations operate with a flatter, less bureaucratic management structure they still require some degree of control over the Web site resource, whether it is an Internet or intranet application. Although the frequently proposed predominance of trust (albeit inconclusive) in virtual enterprises may compensate in some ways for fewer rules and regulations.

\section{METHODOLOGY}

An exploratory study has been undertaken to examine the types of strategies used within organisations to manage the on-going development of their Web sites and to identify a set of strengths and weaknesses associated with each strategy. It is intended that the findings could be used to classify Web site management approaches and provide models and lessons for practitioners and a research agenda for academics. As the Web site resource is of such importance strategically to virtual organisations the findings should be useful in helping them develop appropriate management strategies. 
Table 1: The Pluses and Minuses of a Bureaucratic Approach to Web Site Management

\begin{tabular}{|l|l|l|l|}
\hline $\begin{array}{l}\text { Pluses of } \\
\text { bureaucracy }\end{array}$ & \multicolumn{2}{l}{$\begin{array}{l}\text { Pluses in relation to Web site } \\
\text { management strategy }\end{array}$} & \multicolumn{2}{l}{$\begin{array}{l}\text { Minuses of } \\
\text { bureaucracy }\end{array}$} & $\begin{array}{l}\text { Minuses in relation to Web site } \\
\text { management strategy }\end{array}$ \\
\hline Control & $\begin{array}{l}\text { The management of the Web } \\
\text { site is clearly visible and the } \\
\text { Web site can be aligned to } \\
\text { organisational goals. }\end{array}$ & $\begin{array}{l}\text { Barriers to } \\
\text { change }\end{array}$ & $\begin{array}{l}\text { The decision making process } \\
\text { (committees) becomes so } \\
\text { protracted the Web site is not } \\
\text { kept up to date and does not } \\
\text { evolve. }\end{array}$ \\
\hline Order & $\begin{array}{l}\text { The Web site is easier to } \\
\text { manage and use because it is } \\
\text { clearly structured. }\end{array}$ & $\begin{array}{l}\text { Reduced } \\
\text { employee } \\
\text { satisfaction }\end{array}$ & $\begin{array}{l}\text { Staff do not feel 'owners' of the } \\
\text { site and content. They become } \\
\text { alienated from participating. }\end{array}$ \\
\hline Efficiency & $\begin{array}{l}\text { It leads to an effective use of } \\
\text { organisational resources and } \\
\text { personnel. }\end{array}$ & $\begin{array}{l}\text { Reduced } \\
\text { discretion }\end{array}$ & $\begin{array}{l}\text { Risks (experiments) are not taken } \\
\text { and the potential rewards not } \\
\text { realised. }\end{array}$ \\
\hline Stability & $\begin{array}{l}\text { The Web site can be used to } \\
\text { support organisational goals } \\
\text { and support the status quo. }\end{array}$ & Red tape & $\begin{array}{l}\text { The rules, procedures and } \\
\text { approval mechanisms are so } \\
\text { involved they act as a } \\
\text { disincentive to staff to update and } \\
\text { develop the Web site. }\end{array}$ \\
\hline $\begin{array}{l}\text { Rule by } \\
\text { reason }\end{array}$ & $\begin{array}{l}\text { That rational argument within } \\
\text { the organisation determines the } \\
\text { strategy, functionality, content } \\
\text { and design of the Web site. }\end{array}$ & $\begin{array}{l}\text { Power } \\
\text { seeking }\end{array}$ & $\begin{array}{l}\text { The staff responsible for the Web } \\
\text { management strategy see } \\
\text { themselves as owners of the site } \\
\text { and do not encourage } \\
\text { participation in its development } \\
\text { and evolution. }\end{array}$ \\
\hline
\end{tabular}

Six large organisations were chosen that have large, multi-functional Web sites. The person in each organisation who had the most knowledge about their Web development and management was approached. An interview was conducted with each person. The interviews lasted on average forty-five minutes and were carried out on the organisations' premises during work hours. A series of open-ended questions were asked that covered the key areas of:

- Historical development of the Web site;

- The group that had the responsibility for Web site development;

- The development and contents of the Web site strategy;

- The management structure of the Web strategy team;

- The process and procedures used in the development process (levels of bureaucracy);

- The composition of any Web strategy/development teams;

- Responsibilities for Web content and design;

- Perception of satisfaction with Web management approaches.

In addition to the interviews, the organisations' Web sites were analysed for structure, functionality, content and design.

The interpretation of the findings uses a dialectical hermeneutics approach. Hermeneutics is primarily concerned with the meaning of a text or text analogue (Myers, 1995). The data, which are interview transcripts, are analysed in terms of themes, motifs, and key words in the same way, as a literary text is (Bronsema, \& Keen, 1983). One of the main differences between pure and dialectical hermeneutics is that, in the latter, the researcher does not just accept the opinions of the participants, but tries to evaluate the totality of understandings in a given situation. The role and understanding of the participants are interpreted historically, and in terms of social and political structures and includes the contribution of the researcher in the analysis process. 


\section{INTERVIEW 1: EDITH COWAN UNIVERSITY}

The University has a decentralised system of Web site management and administration. Various faculties, schools and the administrative divisions of the University create, revise and update their Web pages and upload them into the different servers. The organic unity of the site is overseen by the Webmaster (not part of the IT division) in consultation with senior officials of the University, although this is done via a loosely coordinated approach. In reality they have little involvement with the distributed Web site activities. Thus at present, the classical elements of bureaucracy do not seem to prevail in the design and management of the Web site. There is significant flexibility and freedom for individuals within the organisation to develop and add Web pages to the site. This along with the training opportunities in Web design tools made available to academic and non-academic staff members contribute to the process of site building. There is little central regulation and evaluation of individual, School and Faculty Web pages at present.

Internet, Intranet and Extranet technologies are undergoing tremendous changes and acquiring increasing capabilities. This partly explains, along with the rapid evolution of the site, the less regulated approach being used. The University is in the process of organising three different functional groups: a Web management group, a Web content group, and a Web systems group. This is intended to create an effective Web site management strategy.

The current Web site management approach at present appears organic in nature. The main evidence to substantiate this statement is as follows:

- There are few rules and procedures in place.

- There is no deep hierarchy of control and authority.

- There is little division of labour. Any one can develop and a Web page to the site.

- The informal approach is in contrast to the bureaucratic mechanisms that are in place for many of the other processes within the organisation.

\section{INTERVIEW 2: JOONDALUP CITY COUNCIL}

Joondalup is a new city in Western Australia. Joondalup City Council is responsible for such functions as: urban design, waste management, roadwork construction and maintenance, parks and landscaping, health, leisure and community services. The Joondalup City Council Web site was launched as a trial service in 1994 but had very limited functionality. It was developed by the Information Services Division but was taken over and expanded by Library Information Services in January of 1996. The Web site includes:

- Databases to manage and display information on job opportunities, community information and local events.

- Information on Council minutes and agendas.

- Feedback options.

- Intranet that includes manuals and policies, staff telephone numbers, etc.

- Web applications such as an On-line inter-Library loans system.

In the development of the Web site there has been no overall strategy articulated. The Library services Webmaster works with Departments across the Council who propose ideas for the site and so the development has evolved in a bottom-up fashion. The Departments are responsible for the content which is passed on by the managers of the Departments and the Webmaster works on the design aspects to try 
achieve a uniform look and feel to the site. The Webmaster does not drive the overall Web site development but is in charge almost by accident. Historically, the Library Services developed their own site but were then asked to take on extra projects on behalf of other Departments. Hence, there isn't a meta-development team forming policies and procedures for the site. In fact, the Webmaster acts as a "gatekeeper" from a design perspective but has little knowledge or interest in content. He is the only one that can add or amend pages and in his words the Council is "paranoid about the image portrayed to the public". For larger projects representative user teams are used for the duration of the project.

The lack of strategy has meant the site has progressed in a rather ad-hoc fashion, some Departments taking the opportunity to put information and functions on the Web via the Webmaster with others having hardly a Web presence. There are elements of bureaucracy in the running of the site but it could be best described as an ad-hocracy with a design gatekeeper and the user managers responsible for content. The Library Services "Ownership" of the site substantiates the view that there is a lack of top-down strategy with the potential of a "bun fight for ownership" if the Webmaster left.

\section{INTERVIEW 3: ABC BROADCASTING COMPANY}

$\mathrm{ABC}$ Online is one of the most visited Australian Web sites. Australian Broadcasting Corporation's Web site has over fifty thousand Web pages. ABC Online is a multimedia site, with live audio streaming, audio files and occasional video streaming. ABC Online had a humble beginning in 1995, and evolved out of the meeting of all stakeholders in the organization. The guiding principles and policies of the site organization, development and management evolved in the first meeting (the 'Online Style Council').

Functionally, $\mathrm{ABC}$ Online has a collection of diverse autonomous Web sites, each with its own editorial integrity. The co-ordination and development of the site rests with the internal Multimedia Unit. The management of the site is decentralized in nature, with Web developers responsible for their particular site. The overall design is visualized by the multimedia team which sets the design standards. Well defined criteria regulate the process of uploading contents into the site and automated systems are in place to facilitate the process. Though the organization could be broadly termed bureaucratic, with several layers of authority, there is scope for autonomy. Because of the high frequency with which the contents have to be updated, emphasis is on acting quickly, and at times autonomously.

The Management strategy can best be described as a team based approach. The Multimedia Unit acts as a team to oversee the on-going development of the Web site but each unit has a team to develop its own portion of the ABC's site.

\section{INTERVIEW 4: WESCOMM PTY LTD}

WesComm Pty Ltd is a small software development and consulting business. Its Web site provides information about the services and products that are offered. The Web site started two years ago as an intranet and then was developed further for customers and potential customers. The Web site started as an organisational initiative but the Web programmer has the most responsibility for its development. All updates are carried out in-house. There is no organisational team to oversee its 
development but there are guidelines for content and design of Web pages. Content can be proposed by anyone in the organisation but the Web programmer checks the design and content and then the Marketing manager approves it. It is then forwarded to the General Manager for approval.

The organisation was described by the interviewee as closely resembling the organic model, however, the management of the Web site is actually quite bureaucratic in nature. The Web strategy is not mentioned as part of the business strategic plan and is developing on a needs basis rather than adhering to a well documented plan.

\section{INTERVIEW 5: CURTIN UNIVERSITY}

Curtin University has over forty thousand pages in its Web site. It started from the beginning as an Internet to provide information the University. There is now an executive strategy for the Web site that is focused on improving service to students and the image of the University. This executive Web strategy does not appear to be integrated with the University strategic plan.

The management of the Web site' content and design has been tightened up as people were not adhering to the guidelines. There is a style guide and all Web pages are checked for style by the Webmaster. However, personal Web pages are not checked for compliance. The Executive Committee give directions on Web development as far as content and functionality are concerned. Generally, there is some autonomy for individuals to develop Web pages but beyond that there are strict guidelines to follow.

\section{INTERVIEW 6: ALEXANDER COLLEGE}

Alexander College is a private college specialising in a range of university, preuniversity and secretarial courses. The Web site provides College and course related information. Its main purpose is to promote interest in its courses and promote the image of the College. Their is no intranet available to staff. The Web site is strictly managed by a centralised executive team. There is little scope for individual initiative although suggestions can be put to the executive team. Individuals cannot add or update Web site content. An external contractor carries out the updates. The site has a strict design style which must be adhered to.

\section{DISCUSSION}

An examination of Web development processes in organisations reveals that there is a need for effective management. This is especially true for virtual organisations where the Web site is a unifying resource for the organisation. Web sites continually evolve and require a high level of integration, coordination and synergy between different groups. It is a challenge for organisations to design Web sites which are functionally integrated, user-friendly and creative at the same time.

The organisations that have been examined can be classified as using simple, organic, bureaucratic and team/network management strategies in relation to their Web site management (figure 2). The City Council Web site is managed rather like a small business where the webmaster has centralised authority and a wide span of control. This approximates most closely to the simple structure which works within 
the overall Council bureaucracy. The decentralised decision making and low formality characterise the Edith Cowan University Web site management approach which contrasts with the largely bureaucratic structure of the organisation. The $A B C$ is characterised by the use of a meta-development team working with semiautonomous teams in Departments. The other three organisations are most closely aligned to the bureaucratic model.

\section{Strengths and Weaknesses with the Approaches}

There are advantages and disadvantages attached to each management approach. The great benefit of the organic approach with the University Web site is that it is useful for keeping the site up to date and for responding quickly to change. The down side is the lack of adherence to design and content standards which may impact on organisational image.

The Joondalup City Council approach has worked effectively in the past when the Web site has been relatively small. As the Web site grows and Departments make greater demands the situation may become unsustainable for the Webmaster (gatekeeper) who for historical reasons has taken on the entire responsibility for the management of the site. Certain Departments lack a Web presence. There is no real organisational strategy or meta-development team to encourage them to be part of the Web development.

The team/network approach at the $\mathrm{ABC}$ appears to bring both degrees of autonomy and regulation together in a collaborative way. The meta-development team operates within a bureaucratic organisational framework which enables fast responsiveness but also provides standards to protect company image.

The bureaucratic approach has the key advantage of adherence to standards to protect organisational image. However, this can led to slow responsiveness for changes and less creativity in the uses and development of the resource.

\section{Issues For Virtual Organisations}

Managers of virtual corporations must be aware that a conscious decision must be made on how the Web resource will be managed. The virtual organisation must decide what can be gained by adopting a particular management approach in relation to their Web resource. It does not necessarily have to be the same style that is used across the organisation generally or for other resources. Team based approaches appear to work for the $\mathrm{ABC}$ which has clearly defined business units but have to be aligned to organisational standards. The bureaucratic approach requires effort to police and may deter innovative uses of the Web but would probably be most suitable for a conservative organisation that is very concerned about the image it portrays.

The simple form of management structure where most or all authority is vested in one individual is perhaps a low cost structure to follow and may be suitable for a small organisation. However, there are inherent dangers with this model. It places a great deal of responsibility on one person. In a larger organisation the Web strategy should be managed as an organisational resource. The organic approach can be useful for encouraging innovative uses of the Web and can work effectively where there are constant changes required to the content. Consistency of design and 
appropriateness of content can become an issue. Where company image is the overriding issue this is perhaps not the best strategy to adopt.

Table 2: Web Site Management Strategies Used by the Six Organisations

\begin{tabular}{|c|c|c|c|c|c|c|c|}
\hline $\begin{array}{l}\text { Mlanage- } \\
\text { ment } \\
\text { Structure }\end{array}$ & $\begin{array}{l}\text { Structural } \\
\text { Characteristics }\end{array}$ & $\begin{array}{l}\text { Edith } \\
\text { Cowan }\end{array}$ & $\begin{array}{l}\text { Joondalup } \\
\text { Council }\end{array}$ & $\begin{array}{l}\text { Alexand- } \\
\text { er } \\
\text { College }\end{array}$ & $\begin{array}{l}\text { Curtin } \\
\text { Univer- } \\
\text { sity }\end{array}$ & $\begin{array}{l}\text { WesCom- } \\
\text { m } \\
\text { Ltd }\end{array}$ & ABC \\
\hline $\begin{array}{l}\text { Type of } \\
\text { Organisa- } \\
\text { tion }\end{array}$ & & University & Council & $\begin{array}{l}\text { Private } \\
\text { College }\end{array}$ & $\begin{array}{l}\text { Univer- } \\
\text { sity }\end{array}$ & $\begin{array}{l}\text { Small } \\
\text { Business }\end{array}$ & $\begin{array}{l}\text { Broadca } \\
\text {-sting } \\
\text { Compan } \\
\text { y }\end{array}$ \\
\hline \multirow[t]{4}{*}{ Simple } & $\begin{array}{l}\text { low degree of } \\
\text { departmentalisation }\end{array}$ & & No & & & & \\
\hline & $\begin{array}{l}\text { wide spans of } \\
\text { control }\end{array}$ & & Yes & & & & \\
\hline & $\begin{array}{l}\text { authority centralised } \\
\text { in a single person }\end{array}$ & & Yes & & & & \\
\hline & little formalisation & & $\begin{array}{l}\text { Some } \\
\text { formality }\end{array}$ & & & & \\
\hline \multirow[t]{2}{*}{ Matrix } & $\begin{array}{l}\text { dual lines of } \\
\text { authority }\end{array}$ & & & & & & \\
\hline & $\begin{array}{l}\text { combines functional } \\
\text { and product } \\
\text { departmentalisation }\end{array}$ & & & & & & \\
\hline \multirow[t]{4}{*}{$\begin{array}{l}\text { Team - } \\
\text { network }\end{array}$} & $\begin{array}{l}\text { the use of teams as a } \\
\text { central } \\
\text { device to coordinate } \\
\text { work activities }\end{array}$ & & & & & & Yes \\
\hline & $\begin{array}{l}\text { decentralised } \\
\text { decision making to } \\
\text { the team level }\end{array}$ & & & & & & Yes \\
\hline & cross-functional & & & & & & Yes \\
\hline & $\begin{array}{l}\text { works within a } \\
\text { bureaucratic } \\
\text { framework }\end{array}$ & & & & & & Yes \\
\hline \multirow[t]{5}{*}{ Organic } & $\begin{array}{l}\text { low horizontal } \\
\text { differentiation }\end{array}$ & Yes & & & & & \\
\hline & adaptable duties & Yes & & & & & \\
\hline & low formalisation & Yes & & & & & \\
\hline & $\begin{array}{l}\text { informal } \\
\text { communication }\end{array}$ & Yes & & & & & \\
\hline & $\begin{array}{l}\text { decentralised } \\
\text { decision authority }\end{array}$ & Yes & & & & & \\
\hline \multirow[t]{5}{*}{$\begin{array}{l}\text { Bureaucr } \\
\text {-acy }\end{array}$} & $\begin{array}{l}\text { Rigid hierarchical } \\
\text { relationships }\end{array}$ & & & Yes & Partly & Yes & \\
\hline & Fixed duties & & & Yes & Yes & Yes & \\
\hline & High formalisation & & & Yes & Partly & Yes & \\
\hline & $\begin{array}{l}\text { Formalised } \\
\text { Communication } \\
\text { channels }\end{array}$ & & & Yes & Yes & Yes & \\
\hline & $\begin{array}{l}\text { Centralised } \\
\text { decision } \\
\text { authority }\end{array}$ & & & Yes & Partly & Yes & \\
\hline
\end{tabular}

How a Web site is managed is perhaps more critical in a virtual organisation where the Web can may play a very important role in coordination and communication of work. The Web site may have to change frequently and be accessible for changes from many workers. This can be made more difficult if the Web site has to cater to different nationalities and cultures. Virtual organisations are often dynamic organisations which one would assume would require dynamic (constantly changing) Web resources. This all suggests that a flatter management 
structure or organic approach to Web site management is required, especially if it accessible only by the employees in an intranet. In figure 2, the characteristics of the organic approach or structure seem to describe the features most required by the virtual enterprise. However, control mechanisms are still required to monitor strategy and the quality of information presented via the Web.

\section{Issues For Academics}

The management of Web sites as a resource raises some interesting issues for researchers. Although the IS resource or function is largely run along bureaucratic lines there are a number of ways that a Web resource can be managed effectively. Further research in this area could explore the relationships between the organisational structure, the goals of the Web strategy, the authority/freedom dichotomy, and Web site management strategies. It is hoped this will lead to models of Web site management that will be useful to organisations coming to terms with this relatively recent addition to their information infrastructure. Further research could examine if the organic approach to Web site management is most appropriate for virtual organisations. In addition, researchers could investigate the role of trust, professionalism and competence in the decision to adopt a particular management strategy.

\section{CONCLUSIONS}

The six organisations studied provided four different methods of managing their Web resource. There are strengths and weaknesses associated with each method. Although a bureaucratic style of management may seem rational and accountable, alternative methods have their merits. New organisational forms require new management approaches. New organisational resources, in this case, Web sites, require careful thought and consideration in the selection of effective management structures and procedures. Virtual organisations must put a great deal of thought into how they manage their own Web site if they are to bring their employees together in an effective manner and make the most of this enabling technology.

\section{REFERENCES}

1. Ahuja, M. K. \& Carley, K. M. (1998). Network Structure in Virtual Organisations. JCMC 3(4).

2. Bartol, K., Martin, D., Tein, M., Matthews, G. (1998). Management: A Pacific Rim Focus. Australia: McGraw Hill.

3. Bronsema, G.S. \& Keen, P.W.G. (1983). Education intervention and implementation in MIS. Sloan Management Review, 24(4), 35-44.

4. Myers, M. D. (1995). Dialectical hermeneutics: a theoretical framework for the interpretation for the implementation of information systems. Information systems Journal, 5, 51-70.

5. Rittenbruch, M. \& Kahler, H., Cremers, A. B. (1998). Supporting Cooperation in virtual organisations. Proceedings of the International Conference on Information systems, 1998, p3039.

6. Robbins, S. P., Millet, B., Cacioppe, R. \& Water-Marsh, T. (1998). Organisational Behaviour. Prentice Hall.

7. Staples, D. S. \& Ratnasingham, P. (1998). Trust: The Panacea of Virtual Management. Proceedings of the International Conference on Information systems, 1998, p.128-146.

8. Vecchio, P., Hearn, G., Southey, G. (1996). Organisational Behaviour. Harcourt Brace.

9. Yap, A. Y. \& Bjorn-Anderson, N. (1998). Energizing the Nexus of Corporate Knowledge: A Portal Toward the Virtual Organisation. Proceedings of the International Conference on Information systems, 1998, p273-286. 